\title{
Dünyanın En İyi Varış Noktası Türk Mutfağına Biyokimyasal Bakış: Bazı Geleneksel Yemekler ve B Vitamini Kompozisyonları
}

\author{
Büşra Yusufoğlu ${ }^{1}$, Kübra Özkan², Mustafa Yaman $^{2}$, Emine Karakuş ${ }^{1}$ \\ ${ }^{1} Y$ Ildız Teknik Üniversitesi, Fen Edebiyat Fakültesi, KimyaBölümü, İstanbul, Türkiye (ORCID: 0000-0002-9158-9732; 0000-0002-7730-3304) \\ ${ }^{2}$ İstanbul Sabahattin Zaim Üniversitesi, Sağlık Bilimler Fakültesi, Beslenme ve Diyetetik Bölümü, İstanbul, Türkiye (ORCID: 0000-0002-7268-3571; 0000-0001-9692-0204)
}

(İlk GelişTarihi 25 Temmuz 2019 ve Kabul Tarihi 25 Ağustos 2019)

(DOI:10.31590/ejosat.596813)

ATIF/REFERENCE: Yusufoğlu, B., Özkan, K., Yaman, M. \& Karakuş, E. (2019). Dünyanın En İyi Varış Noktası Türk Mutfağına Biyokimyasal Bakış: Bazı Geleneksel Yemekler ve B Vitamini Kompozisyonları. Avrupa Bilim ve Teknoloji Dergisi, (16), 874-880.

\begin{abstract}
$\ddot{O} \mathbf{z}$
Geleneksel Türk mutfağında mevcut olan yemeklerin porsiyon başına düşen vitamin kompozisyonlarının miktarı ve günlük alınması gereken değerler arasında bir ilişki söz konusudur. Bu çalışma da, bu ilişkiyi incelemek amacıyla bazı geleneksel yemek türleri laboratuvar ortamında hazırlanarak, HPLC (Yüksek Performanslı Sıvı Kromatografisi) cihazı aracılı̆̆ıyla analiz edildi. Kullanılan analitik yöntemle, suda çözünen bazı vitaminlerin eşzamanlı tespiti yapılarak miktar tayini için spesifik, sağlam ve zaman açısından verimli olduğu gösterildi. Her bir örnek için tiamin, riboflavin, nikotinik asit, nikotinamid, piridoksin (PN), piridoksal (PL) ve piridoksamin (PM) kompozisyonları incelendi ve sonuçlar mikrogram $(\mu \mathrm{g})$ cinsinden hassas bir şekilde ifade edildi. B vitamini kompozisyonları dokularda oluşan oksidatif hasarlara karşı güçlü bir aktiviteye sahip antioksidanlar arasındadır. Ayrıca karbohidrat ve enerji metabolizması için de önemli bir rol oynar. Bu çalışmanın temel amacı günlük hayatta tüketilen bazı geleneksel yemek türlerinin 1 porsiyonunda bulunan B vitamini değerlerini $\mu \mathrm{g}$ olarak bulmaktır. Aynı zamanda, günlük B vitamini ihtiyacının ne kadarını karşıladığını yüzde olarak sunmaktır. Analizler sonucunda en yüksek $B_{1}$ ve $B_{2}$ vitamini miktarına sahip olan besin mercimek köftesidir, değerleri sırasıyla $299.20 \mu \mathrm{g} /$ porsiyon ve $364.32 \mu \mathrm{g} /$ porsiyon şeklindedir. B 3 vitaminin en yüksek olduğu besin zeytinyağlı yaprak sarmadır ve değeri $1030.4 \mu \mathrm{g} /$ porsiyon olarak bulunmuştur. Son olarak $\mathrm{B}_{6}$ vitaminin en yüksek olduğu besin 623.0 $\mu \mathrm{g} /$ porsiyon ile Kayseri mantıda bulunmuştur. Yemeklerin 1 porsiyonlarının günlük B grubu vitamin ihtiyacımızı karşılama oranları ise sirasiyla: Kayseri mant1; $\mathrm{B}_{1} \% 8.75, \mathrm{~B}_{2} \% 10.3 \mathrm{~B}_{3} \% 4.70, \mathrm{~B}_{6} \% 47.9$, lahmacun; $\mathrm{B}_{1} \% 16.5, \mathrm{~B}_{2} \% 7.38, \mathrm{~B}_{3} \% 1.55, \mathrm{~B}_{6} \% 26.5$, zeytinyağlı yaprak sarma; $\mathrm{B}_{1} \% 3.60, \mathrm{~B}_{2} \% 7.87, \mathrm{~B}_{3} \% 7.33$, $\mathrm{B}_{6} \% 6.86$, mercimek köftesi; $\mathrm{B}_{1} \% 24.9, \mathrm{~B}_{2} \% 28.0, \mathrm{~B}_{3} \% 3.44, \mathrm{~B}_{6} \% 24.1$ şeklindedir.
\end{abstract}

Anahtar Kelimeler: B vitamin kompozisyonları, geleneksel yemek türleri, HPLC

\section{The world's best destination biochemical insight into the Turkish cuisine: Some traditional foods and B vitamins compositions}

\begin{abstract}
There is a relationship between the vitamin amount of the currently serving traditional Turkish cuisine compositions and values that should be taken daily. In this study, some traditional food types were prepared in laboratory and analyzed by means of HPLC (High Performance Liquid Chromatography) so as to examine this relationship. By analytical method used, some water-soluble vitamins simultaneous identification by doing, spesific for amount of quantification, robust and efficient in terms of time was shown. For each sample, composition of thiamine, riboflavin, nicotinic acid, nicotinamide, pyridoxine (PN), pyridoxal (PL) and pyridoxamine (PM) was analyzed and results were expressed as a micrograms $(\mu \mathrm{g})$, sensetively. Vitamin B compositions are among the antioxidants that have a strong activity against oxidative damage to tissues. Furthermore, it also plays an important role in carbohydrate and energy metabolism.

The main purpose of this paper, find the values of some types of traditional foods consumed in daily life in order to find as a microgram of $\mathrm{B}$ vitamins in 1 portion. At the same time, to provide the daily vitamin $\mathrm{B}$ requirements as percentage. As a result of analyzes, mercimek köftesi has the highest $\mathrm{B}_{1}$ and $\mathrm{B}_{2}$ amounts were $299.20 \mu \mathrm{g} /$ portion and $364.32 \mu \mathrm{g} / \mathrm{portion}$ respectively. The highest vitamin $\mathrm{B}_{3}$ containing meal is zeytinyağlı yaprak sarma with $1030.4 \mu \mathrm{g} /$ portion and lastly the highest vitamin $\mathrm{B}_{6}$ containing meal is found in Kayseri mant1 with $623.0 \mu \mathrm{g} /$ portion. The ratios of 1 portion of meals to cover our daily vitamin B requirements are
\end{abstract}

\footnotetext{
*Sorumlu Yazar: Yıldız Teknik Üniversitesi, Fen-Edebiyat Fakültesi, Kimya Bölümü, İstanbul, Türkiye, ORCID:0000-0002-9158 9732, yusufoglubusra@gmail.com
} 
as follows: Kayseri mant; $\mathrm{B}_{1} 8.75 \%, \mathrm{~B}_{2} 10.3 \% \mathrm{~B}_{3} 4.70 \%, \mathrm{~B}_{6} 47.9 \%$, lahmacun; $\mathrm{B}_{1} 16.5 \%, \mathrm{~B}_{2} 7.38 \%$, $\mathrm{B}_{3} 1.55 \%$, $\mathrm{B}_{6} 26.5 \%$, zeytinyağl1 yaprak sarma; $\mathrm{B}_{1} 3.60 \%, \mathrm{~B}_{2} 7.87 \%, \mathrm{~B}_{3} 7.33 \%, \mathrm{~B}_{6} 6.86 \%$ and mercimek köftesi; $\mathrm{B}_{1} 24.9 \%, \mathrm{~B}_{2} 28.0 \%, \mathrm{~B}_{3} 3.44 \%, \mathrm{~B}_{6} 24.1 \%$.

Keywords: Compositions of vitamin B, traditional types of meals, HPLC

\section{Giriş}

Bir toplumun yeme içme alışkanlıklarını, yaşadığı yörenin coğrafik, tarımsal ve sosyo-kültürel özelliklerinin yanı sıra başka toplumlarla olan etkileşimi de belirler. Günümüz Türk mutfağının şekillenmesinde ve zenginleşmesinde, Türkiye'de yaşamış olan uygarlıkların etkisi büyüktür. Bu açıdan,Türk mutfak kültürünün yapısı Orta Asya Türk mutfağı, Selçuklu mutfağı, Osmanlı mutfağı ve son olarak da Cumhuriyet Dönemi mutfağının zenginliklerinden etkilenmiştir (Kızıldemir, Öztürk ve Sarışık, 2014).Geleneksel Türk mutfağını incelediğimizde et, tahıl, bakliyat, yaş veya kurutulmuş sebze ve meyveler, süt ve süt ürünlerinden oluştuğu görülmektedir (Ertaş ve Gezmen, 2013).

Vitaminler; yağda ve suda eriyen vitaminler olmak üzere 2 gruba ayrılır. Suda eriyen vitaminler; $\mathrm{B}_{1}, \mathrm{~B}_{2}, \mathrm{~B}_{3}, \mathrm{~B}_{6}, \mathrm{~B}_{12}, \mathrm{folik}_{0}$ asit pantotenik asit, biotin ve askorbik asit vitaminidir (Güngör, 2003). B 1 vitamininin, besinlerle vücuda alınan besin öğelerinin enerjiye çevrilmesinde ve karbonhidratlardan enerji elde edilmesi sırasında önemli bir işlevi vardır (Samur, 2008). Karbonhidrat metabolizmasında önemli göreve sahip olduğu için, tüketime bağlı olarak gereksinim artar. Bunun sebebi, karbonhidratların parçalanmasında, glikozun farklı basamaklar üzerinden pirüvata dönüşümüdür. $\mathrm{B}_{1}$ (tiamin) vitamini, glikojenin pirüvata çevrilmesi ve asetilkoenzim A’nın çalışmasında önemli rol oynar. Yetişkin bir insanın günlük tiamin ihtiyac1 1-2 mg/gün'dür. Tiamin, tahıl ürünlerinin dış tabakalarında oldukça fazla bulunmaktadır. Tiamin eksikliği karbonhidrat metabolizmasında bozulmalara sebep olur ve bunun sonucunda kas ve sinir sisteminde hastalıklar gözlenir (Demirci, 2014).

Biyokimyasal olarak metabolizmaya etkisi incelendiğinde, $\mathrm{B}_{2}$ (riboflavin) vitamini, doğada aktif olarak flavin mono nükleotid (FMN) ve flavin adenin dinükleotid (FAD) formlarında bulunur. Bu iki form beslenme açısından aynı aktiviteyi gösterirler ayrıca yükseltgenme ve indirgenme süreçlerini katalizleyen birçok enzim için koenzim olmalarına ek olarak hidrojen taşınmasında görev almaktadırlar. Gidalarda ve sindirim sisteminde bulunan fosfataz enzimlerinin aktivitesi sonucunda FMN ve FAD riboflavin formuna dönüşmektedir (Boyacı, 2008). Yetişkinler için önerilen ortalama doz 3 mg/gün’ dür (Tayar, Korkmaz ve Özkeleş, 2013).

$\mathrm{B}$ vitamin kompozisyonları içerisinde bulunan bir diğer formda $\mathrm{B}_{3}$ (Niasin) vitaminidir. Bu form, laktat dehidrogenaz (LDH) ve malat-dehidrogenazın koenzimi olan nikotinamid adenin dinükleotid (NAD) ve nikotinamid adenin dinükleotid fosfat (NADP) sentezinde işlev görür. Ayrıca, solunum için gerekli olan enzimlerin aktive ederek hücrelerin oksijeni kullanmasını sağlar. Nikotinik asit, besinlerde bulunan triptofan yoluyla vücutta sentez edilebilir. Beslenme ile alınan $60 \mathrm{mg}$ triptofandan $1 \mathrm{mg}$ nikotinik asit sentez edilir (Barut, 2016).

Biyokimyasal olarak B6 vitamininin, en etkili formu piridoksal fosfattır (Bingöl, 1977). Bu vitaminde organizmada piridoksal fosfata dönüşen 3 etkili bileşik tanınmaktadır. Bunlar; piridoksal, piridoksin ve piridoksamin adlı 3 yapıdır. Piridoksin bitkilerde piridoksal ve piridoksamin hayvansal gıdalarda bulunur. $\mathrm{B}_{6}$ vitamini, protein metabolizmasının ana koenzimi olan piridoksal fosfatın (PLP) biyosentezinde çıkış maddesidir. Piridoksin fosfat olarak, metabolizmada amino gruplarını taşıma özelliği olduğundan dolayı transaminazların koenzimi olarak görev yapar. Ayrıca yardımcı enzimleri, yă ve karbonhidrat metabolizmasında da bazı reaksiyonların yürütülmesine yardımcı olur (Demirci, 2014). Piridoksal fosfat; tirozin, arginin, glutamik asit ve diğer bazı amino asitlerin dekarboksilasyonunda görevli enzimlerin prostetik grubunu oluşturur. Piridoksal fosfat ayrıca serin ve treoninin aminasyonunda koenzim olarak görev yapar. Piridoksal fosfatın diğer bir önemli rolü de transaminasyon sırasında görülür. Piridoksalın hücre zarlarından amino asitlerin aktif transportasyonunu kolaylaştırdığı düşünülmektedir. Ayrıca piridoksal fosfat transsülfirasyon, sistein ve homosisteinin desülfirasyonunda da rol oynamaktadır (Bingöl, 1977). B6 vitamini çoğunlukla protein metabolizması ile ilgili olduğundan, diyetteki protein miktarının artışına paralel olarak B6'ya ihtiyaç vardır. Yetişkinler için $1 \mathrm{~g}$ protein üzerinden $0.016 \mathrm{mg}$ önerilmektedir (Demirci, 2014).

Yaşam tarzı, sigara kullanımı ve özellikle de alkol tüketimi vitamin biyoyararlılığı üzerinde bazı etkilere sahiptir. Aşırı kronik alkol alımı, yetersiz beslenme, malabsorpsiyon ve etanol toksisitesine bağlı olarak vitamin eksikliği (özellikle folat, tiamin ve $B_{6}$ vitamini) gözlenebilir. Alkol gibi kahve tüketimi de plazma homosistein seviyesini arttırır ancak vitamin emilimi veya kullanımı üzerinde bir etkisi olmadığ belirtilmiştir. Bunun dışında $\mathrm{B}_{6}$ plazma seviyelerinde egzersize bağlı değişiklikler olabilir ancak vitamin emilimini etkilemediği belirtilmiştir. Ayrıca vitaminlerin biyoyararlılığı, bazı sebzelerden (özellikle çiğ) veya yüksek lifli yiyeceklerden vitaminlerin yetersiz salınması nedeniyle azalabilir (Van den Berg vd., 2002).

Bu çalışmanın amacı, Türkiye’ye özgü olan bazı yemek türlerinin içerdiği $\mathrm{B}_{1}, \mathrm{~B}_{2}, \mathrm{~B}_{3}$ ve $\mathrm{B}_{6}$ vitamin kompozisyonlarının günlük enerji ihtiyacının ne kadarını karşıladığını ortaya koyarak, sonuçları enerji ve karbohidrat metabolizması açısından değerlendirmektir.

\section{Materyal ve Metot}

Bu çalışmada ayrı ayrı her bir yemek türü için farklı analiz metodları modifiye edildi (Esteve, vd., 2001; Ndaw, vd., 2002; Sampson 1995). Bu çalışmada analiz edilen 4 çeşit yemek için tüm hammaddeler İstanbul'da bulunan yerel marketlerden satın alınarak laboratuvar ortamında, geleneksel servis usulüne uygun bir şekilde hassas terazi ile tartılarak hazırlandı. Bunlar sırasıyla Kayseri mantı, lahmacun, zeytinyağlı yaprak sarma ve mercimek köfte şeklindedir (Tablo 1). 
Tablo 1. Çalışmada Kullanılan Geleneksel Yemek Türleri

\begin{tabular}{lccc}
\hline Besinler & 1 porsiyon/gram & Ek Malzeme & Gram \\
\hline Kayseri mantı & 250 & ------- & ------- \\
\hline Lahmacun (1 adet) & 123 & Domates & 80.5 \\
& & Soğan & 47.0 \\
& & Marul & 25.0 \\
& & Limon & 28.0 \\
\hline Zeytinyağlı yaprak sarma & 160 & Limon & 30.3 \\
\hline Mercimek köfte & 176 & Marul & 55.7 \\
& & Limon & 30.0 \\
\hline
\end{tabular}

Hidroklorik asit çözeltisi, taka diastaz, ortofosforik asit Sigma Chem. Co. (St. Louis, MO), sodyum hidroksit çözeltisi FlukaAnalytical, potasyum ferrisiyanid çözeltisi (\%1) Sigma Chem. Co. (St. Louis, MO), sodyum asetat çözeltisi (2.5 M) Isolabchemicals, tiamin stok çözeltisi Sigma Chem. Co. (St. Louis, MO) marka satın alındı. Bu çalışmada, çalkalamalı su banyosu (Memmert), pH metre (HANNA instruments HI 2211 PH/ORP Meter), ultrasonik su banyosu (Selectaultrasons H-D), otoklav (SelectaPresoclave - II), otomatik pipet (100/1000 $\mu 1-5 / 50 \mu 1-2 / 200 \mu 1)$, (Axypet - Autoclavable), $0.45 \mu \mathrm{m}$ CA filtre (Chromafil CA45/25), santrifüj (Hitachi CR22N) ve buzdolabı (Uğur) marka kullanıldı. Çalışmada kullanılan tüm kimyasallar analitik saflıkta ve kullanılan çözeltiler analiz sırasında distile su ile Direct-Q 3 UV ultrapure sistemi kullanılarak hazırlandı. Analiz sonuçları, Shimadzu Nexera-i LC - 2040C 3D marka HPLC cihazı kullanılarak elde edildi.

\subsection{B1 Vitamini (Tiamin) Tayini}

\subsubsection{Standard Hazırlama}

Her bir örnek için, standard tiamin stok çözeltisini çözmek amacıyla $0.1 \mathrm{~N}$ hidroklorik asit çözeltisi hazırlandı. Çalışma sırasında kullanılan her bir standard çözeltisi günlük olarak, analiz için hazırlandı.

\subsection{2. Ö̈neğin Homojenize Edilmesi}

Homojenize edilmiş $10 \mathrm{~g}$ örnek $100 \mathrm{~mL}$ 'lik erlen içerisinde tartıldı, üzerine $60 \mathrm{~mL} 0.1 \mathrm{~N}$ hidroklorik çözeltisi ilave edildi. Daha sonra $121^{\circ} \mathrm{C}$ 'de $30 \mathrm{dk}$ otoklavlandı. Örnekler oda sıcaklığına kadar soğutuldu ve $2.5 \mathrm{M}$ sodyum asetat çözeltisi ile pH $4.5^{\prime}$ e ayarlandı. Örneğin üzerine $100 \mathrm{mg}$ takadiastaz ve $5 \mathrm{mg}$ asit fosfataz ilave edildikten sonra çalkalamalı su banyosunda $45^{\circ} \mathrm{C}$ 'de 3 saat süre ile inkübe edildi. Süre sonunda oda sıcaklığına gelene kadar soğutuldu ve hacim $100 \mathrm{~mL}$ olacak şekilde $0.1 \mathrm{~N}$ HCI çözeltisi ile tamamlandıktan sonra adi filtre kağıdından süzüldü ve son olarak $0.45 \mu \mathrm{m}$ filtreden süzülerek HPLC' ye enjekte edildi.

\subsection{3. $B_{1}$ Vitaminin HPLC ile Belirlenmesi}

B 1 vitamini analizi Shimadzu Nexera-i LC - 2040C 3D (Shimadzu Corporation, Kyoto, Japan) marka HPLC cihazında yapıldı. Mobil faz distile su ve asetonitril ile (85:15) hazırlandı. Floresans dedektörde, eksitasyon dalga boyu ve emisyon dalga boyu sırasıyla

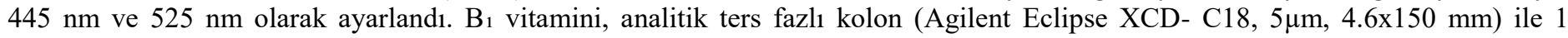
$\mathrm{mL} /$ dakika akış hızıyla ayrıldı.

\subsection{B 2 (Riboflavin) Vitamini Tayini}

\subsubsection{Standard Hazırlama}

Her bir örnek için, standard riboflavin stok çözeltisini çözmek amacıyla $0.1 \mathrm{~N}$ hidroklorik asit çözeltisi hazırlandı. Çalışma sırasında kullanılan her bir standard çözelti günlük olarak, analiz için hazırlandı.

\subsection{2. Örneğin Homojenize Edilmesi}

Homojenize edilmiş $10 \mathrm{~g}$ örnek $100 \mathrm{~mL}$ 'lik erlen içerisinde tartıldı, üzerine $60 \mathrm{~mL} 0.1 \mathrm{~N}$ hidroklorik çözeltisi ilave edildi. $121^{\circ} \mathrm{C}$ 'de $30 \mathrm{dk}$ otoklavlandındıktan sonra örnekler oda sıcaklığına kadar soğutuldu ve $2.5 \mathrm{M}$ sodyum asetat çözeltisi kullanılarak pH 4.5'e ayarland1. Örneğin üzerine $100 \mathrm{mg}$ takadiastaz, $5 \mathrm{mg}$ asit fosfataz, $1 \mathrm{mg}$ distile su ilave edildi. 


\subsection{3. $\quad B_{2}$ vitaminin HPLC ile Belirlenmesi}

$\mathrm{B}_{2}$ vitamini analiz sonuçları, Shimadzu Nexera-i LC - 2040C 3D (Shimadzu Corporation, Kyoto, Japan) marka HPLC cihazı kullanılarak elde edildi. Mobil faz distile su ve asetonitril ile (85:15) hazırlandı. Floresans dedektör, eksitasyon dalga boyu ve emisyon dalga boyu sırasıyla $445 \mathrm{~nm}$ ve $525 \mathrm{~nm}$ olarak ayarlandı. $\mathrm{B}_{2}$ vitamini, analitik ters fazlı kolon (Agilent Eclipse XCD- C18, $5 \mu \mathrm{m}, 4.6 \times 150 \mathrm{~mm}$ ) ile $1 \mathrm{~mL} /$ dakika akış hızıyla ayrıldı.

\subsection{B $_{3}$ (Niasin) Vitamini Tayini}

\subsubsection{Standard Hazırlama}

Her bir örnek için, standard nikotinik asit ve nikotinamid stok çözeltilerinden $100 \mathrm{ml}$ 'lik balon joje içine $10 \mathrm{mg}$ tartıldı ve bir miktar $0.1 \mathrm{~N}$ hidroklorik asit ile çözündürüldü ve son hacime tamamlandı. Gerekli seyreltme işlemi yapıldıktan sonra 1, 2, 3, 4 $\mu \mathrm{g} / \mathrm{mL}$ 'lik çalışma standardları hazırlandı.

\subsection{2. Örnek Hazırlama}

Homojenize edilmiş $10 \mathrm{~g}$ örnek $250 \mathrm{~mL}$ 'lik erlene konularak tartıldı üzerine $60 \mathrm{~mL} 0.1 \mathrm{~N}$ hidroklorik asit ilave edildikten sonra $121^{\circ} \mathrm{C}$ 'de $30 \mathrm{dk}$ otoklavlandı ve daha sonra örnekler oda sicaklı̆̆ına gelinceye kadar soğutuldu. Son hacim $0.1 \mathrm{~N}$ hidroklorik asitle tamamlandıktan sonra adi filtre kağıdından süzülerek $0.45 \mu \mathrm{m}$ filtreden geçirildi ve HPLC'ye enjekte edildi.

\subsubsection{B B Vitaminin HPLC ile Belirlenmesi}

$B_{3}$ vitamini analiz sonuçları, Shimadzu Nexera-i LC - 2040C 3D (Shimadzu Corporation, Kyoto, Japan) marka HPLC cihazı kullanılarak elde edildi. Mobil faz distile su ve asetoniril ile 85:15 oranında hazırlandı. Floresans dedektör, eksitasyon dalga boyu ve emisyon dalga boyu sirasıyla $322 \mathrm{~nm}$ ve $380 \mathrm{~nm}$ olarak ayarlandı. B $_{1}$ vitamini, analitik ters fazlı kolon (Agilent Eclipse XCD- C18, $5 \mu \mathrm{m}, 4.6 \times 150 \mathrm{~mm}$ ) ile $1 \mathrm{~mL} /$ dakika akış hızıyla ayrıldı.

\subsection{B Vitamini Tayini}

$\mathrm{B}_{6}$ vitaminin analizi Bölüm 2.2.' de belirtilen $\mathrm{B}_{2}$ vitamini ile aynı metod kullanılarak yapıldı, fakat $\mathrm{B}_{6}$ tayini yapılırken çalkalamalı su banyosunda 18 saat inkübe edildi.

\section{Araştırma Sonuçları ve Tartışma}

$\mathrm{Bu}$ çalışmada bazı geleneksel yemeklerde bulunan $\mathrm{B}_{1}$ vitamin değerleri Tablo 2' de verilmiştir. En yüksek $\mathrm{B}_{1}$ vitaminine sahip geleneksel yemek türü olan mercimek köftesinin 1 porsiyonunda (176 g) $299.20 \mu \mathrm{g} \mathrm{B}_{1}$ vitamini bulunmaktadır. Mercimek köftesinin, yetişkin bireylerde günlük $\mathrm{B}_{1}$ vitamini gereksinimini karşılama oranı $\% 24.9$ ' dur.

Tablo 2. Analiz sonucunda, bazı geleneksel yemek türlerinden elde edilen $B_{1}$ vitamin miktarı

\section{Geleneksel Yemek Türleri}

$$
B_{1} \text { vitamini }(\mu \mathrm{g} / \mathbf{1 0 0} \mathrm{g})
$$

\section{$B_{1}$ vitamini ( $\mu \mathrm{g} /$ Porsiyon)}

Günlük gereksinim(\%)

\begin{tabular}{llll}
\hline Kayseri mantı & $41.9 \pm 1.9$ & 105.0 & 8.75 \\
\hline Lahmacun & $160.5 \pm 7.3$ & 198.03 & 16.5 \\
\hline Zeytinyağlı yaprak sarma & $26.9 \pm 1.2$ & 43.200 & 3.60 \\
\hline Mercimek köfte & $169.4 \pm 7.7$ & 299.20 & 24.9 \\
\hline
\end{tabular}

$\mathrm{Bu}$ çalışmadaki bazı geleneksel besinlerde bulunan $\mathrm{B}_{2}$ vitamin miktarları Tablo 3' de verilmiştir. En yükssek $\mathrm{B}_{2}$ vitaminine sahip geleneksel yemek türü olan mercimek köftesinin 1 porsiyonunda (176 g) $364.32 \mu \mathrm{g} \mathrm{B} \mathrm{B}_{2}$ vitamini bulunmaktadır. Mercimek köftesinin, yetişkin bireylerde günlük $\mathrm{B}_{2}$ vitamini gereksinimini karşılama oranı $\% 28.0$ ' dir. 


\begin{tabular}{llll} 
Geleneksel Yemek Türleri & $\mathbf{B}_{2}$ vitamini $(\boldsymbol{\mu g} / \mathbf{1 0 0} \mathbf{g})$ & $\mathbf{B}_{2}$ vitamini $(\boldsymbol{\mu g} /$ Porsiyon) & Günlük gereksinim(\%) \\
\hline Kayseri mantı & $53.8 \pm 2.4$ & 135.00 & 10.3 \\
\hline Lahmacun & $77.7 \pm 3.5$ & 95.940 & 7.38 \\
\hline Zeytinyağlı yaprak sarma & $63.8 \pm 2.9$ & 102.40 & 7.87 \\
\hline Mercimek köfte & $206.3 \pm 9.3$ & 364.32 & 28.0
\end{tabular}

$\mathrm{Bu}$ çalışmada kullanılan geleneksel besinlerde bulunan $\mathrm{B}_{3}$ (Niasin) vitaminin formlarının miktarları Tablo 4' de verilmiştir. B 3 vitamini için en yüksek değer 1 porsiyon (160 g) zeytinyağlı yaprak sarma $1030.4 \mu \mathrm{g}$ olarak bulunmuştur. Zeytinyağlı yaprak sarmanın, yetişkin bireylerde günlük $\mathrm{B}_{3}$ vitamin gereksinimlerini karşılama oranı ise \%7.33' dür.

Tablo 4. Analiz sonucunda, bazı geleneksel yemek türlerinde elde edilen Bз vitaminin nikotinikasit ve nikotinamid formlarının miktarı

\begin{tabular}{llllll}
\hline Geleneksel Yemek Türleri & $\begin{array}{l}\text { Nikotinik asit } \\
(\boldsymbol{\mu g} / \mathbf{1 0 0} \mathbf{g})\end{array}$ & $\begin{array}{l}\text { Nikotinamid } \\
(\boldsymbol{\mu g} / \mathbf{1 0 0} \mathbf{g})\end{array}$ & $\begin{array}{l}\text { Toplam } \mathbf{B}_{\mathbf{3}} \\
(\boldsymbol{\mu g} / \mathbf{1 0 0} \mathbf{g})\end{array}$ & $\begin{array}{l}\mathbf{B}_{3} \text { vitamini } \\
(\boldsymbol{\mu g} / \mathbf{p o r s i y o n})\end{array}$ & $\begin{array}{c}\text { Günlük gereksinim } \\
\mathbf{( \% )}\end{array}$ \\
\hline Kayseri mantı & $85.7 \pm 3.9$ & $169.4 \pm 7.7$ & 256.00 & 640.00 & 4.70 \\
\hline Lahmacun & $33.9 \pm 1.5$ & $143.5 \pm 6.5$ & 178.00 & 218.94 & 1.55 \\
\hline Zeytinyağlı yaprak sarma & $139.5 \pm 6.3$ & $502.3 \pm 22.7$ & 644.00 & 1030.4 & 7.33 \\
\hline Mercimek köfte & $106.6 \pm 4.8$ & $167.4 \pm 7.6$ & 275.00 & 484.00 & 3.44 \\
\hline
\end{tabular}

Bu çalışmadaki bazı geleneksel besinlerde bulunan $\mathrm{B}_{6}$ vitamininin formlarının miktarları Tablo 5' de verilmiştir. B 6 vitamin için en yüksek değer 1 porsiyon (250 g) Kayseri mantı $640.00 \mu$ g olarak bulunmuştur ve Kayseri mantının yetişkin bireylerde günlük B6 vitamin gereksinimlerini karş1lama oranı \% 47.9 'dur.

Tablo 5. Analiz sonucunda, bazı geleneksel yemek türlerinden elde edilen B6 vitaminin PL, PN ve PM formlarının miktarı

\begin{tabular}{lllllll}
\hline Geleneksel Yemek Türleri & $\begin{array}{l}\text { PL } \\
(\boldsymbol{\mu g} / \mathbf{1 0 0} \mathbf{g})\end{array}$ & $\begin{array}{l}\text { PN } \\
(\boldsymbol{\mu g} / \mathbf{1 0 0} \mathbf{g})\end{array}$ & $\begin{array}{l}\text { PM } \\
(\boldsymbol{\mu g} / \mathbf{1 0 0} \mathbf{g})\end{array}$ & $\begin{array}{l}\text { Toplam B6 } \\
(\boldsymbol{\mu g} / \mathbf{1 0 0} \mathbf{g})\end{array}$ & $\begin{array}{l}\text { B6 vitamini } \\
(\boldsymbol{\mu g} / \mathbf{p o r s i y o n})\end{array}$ & $\begin{array}{c}\text { Günlük } \\
\text { gereksinim } \\
(\boldsymbol{\%})\end{array}$ \\
\hline Kayseri Mantı & $194.4 \pm 8.8$ & $45.8 \pm 2.1$ & $9.0 \pm 0.4$ & 249.2 & 623.00 & 47.9 \\
\hline Lahmacun & $24.9 \pm 1.1$ & $119.6 \pm 5.4$ & $136.5 \pm 6.2$ & 281.0 & 345.63 & 26.5 \\
\hline Zeytinyağlı yaprak sarma & $17.9 \pm 0.8$ & $22.9 \pm 1.0$ & $15.0 \pm 0.7$ & 55.80 & 89.280 & 6.86 \\
\hline Mercimek köfte & $30.9 \pm 1.4$ & $65.8 \pm 3.0$ & $81.7 \pm 3.7$ & 178.4 & 313.98 & 24.1 \\
\hline
\end{tabular}

Ülkemizde ve dünyada son yıllarda sağlıklı beslenme konusunda giderek daha bilinçli hareket etme isteği artmaktadır. Beslenme, hem yaşamımızı sürdürebilmek hem de sağlıklı kalabilmemiz için çok önemlidir. Bu açıdan bakıldığında ülkemizde çok sık tüketilen geleneksel besinlerin içeriğini bilmek önem kazanır. Literatürde, ülkemize ait olan geleneksel besinlerin B vitamin kompozisyonlarıyla ilgili çalışmaya rastlanmamış olması bu çalışmanın özgün olduğunu göstermektedir. Çalışılan örnekler açısından benzer bir yayın yoktur fakat farklı örneklerle benzer metodlar kullanılmıştır.

Ciulu vd. (2010)'da 12 farklı bitkisel kökenli 28 bal örneğinde bulunan suda çözünen vitaminlerin analizi RP-HPLC (Ters Faz Yüksek Performanslı Sıvı Kromatografi) kullanılarak yapılmıştır. Aslında şeker bazlı matrikslerde vitamin analizlerine çok fazla rastlanmamaktadır. Bu çalışmada, , suda çözünebilir beş vitaminin $\left(\mathrm{B}_{2}\right.$ vitamini, riboflavin; $\mathrm{B}_{3}$ vitamini, nikotinik asit; $\mathrm{B}_{5}$ vitamini, pantotenik asit; $\mathrm{B}_{9}$ vitamini, folik asit ve $\mathrm{B}_{5}$ vitamin) aynı anda belirlenmesi için basit ve hızlı bir RP-HPLC yöntemi önerilmiştir. Bu 
yöntem düşük miktarda tespit ve geniş bir konsantrasyon aralığında çok iyi bir doğrusallık ve hassasiyet sağlamıştır. Çalışma sonucunda hemen hemen tüm bal örneklerinde $\mathrm{C}$ vitamini ve $\mathrm{B}_{3}$ vitamini olduğu gözlenmiştir (Ciulu vd., 2010).

Rose - Sallin vd. (2000)'de yapmış olduğu çalışmada takviye edilmiş bazı gıda ürünlerinde niasin tayini için mikrobiyolojik ve HPLC floresans saptama yöntemleri karşılaştırılmıştır. Bu çalışmada örnek olarak süt, tahıl ürünleri, kahvaltılık gevrek ve sıvı olan klinik besinler kullanılmıştır. Çalışmada önerilen HPLC metodu ters faz kromatografisi, post kolon türevlendirme ve floresansa dayanan tespit yöntemi gibi üstünlük sağlayan parametrelerden dolayı tahıl ve süt bazlı ürünlerde niasinin belirlenmesi için çok özel, seçici ve uygun bir yöntem olduğu gösterilmiştir. Bununla birlikte HPLC yöntemi yiyeceklerde mikrobiyolojik analizden biraz daha düşük olan niasin değerleri verir. Çalışma, tahıl bazlı ürünler için önemli farklılıklar sunmuştur. Ayrıca sonuçlar incelendiğinde elde edilen HPLC değerlerinin, gıdadaki gerçek biyolojik olarak kullanılabilir niasin konsantrasyonlarına mikrobiyolojik değerlerden daha yakın olduğu gösterilmiştir (Rose - Sallin vd., 2000).

El-Arab vd. (2003)'de yaptıkları çalışmada, Mısır'ın 240 farklı temel gıdasının $B_{1}$ vitamini açısından yeterliliği araştırılmıştır. Bu çalışmada da enzimatik sindirim, türevlendirme ve HPLC ayrılması sonrasında veriler değerlendirilmiştir. Analiz edilen gıdalardan, mısır nişastası pudingi en düşük $0.001 \mathrm{mg}(100 \mathrm{~g})$ iken, ev yapımı ekmek (battawi) ise $0.672 \mathrm{mg}(100 \mathrm{~g})$ olarak en yüksek bulunmuştur. Bu çalışmanın sonuçları, Mısır nufüsunun tahmini günlük $B_{1}$ vitamini alımının \% 70'lik kısmının ekmek ve diğer tahıl ürünlerinden karşılandığını göstermiştir (El-Arab vd., 2003).

Yaman ve Mızrak (2019)'da yaptıkları çalışmada 13 farklı tahıl bazlı bebek mamasında B 6 vitamininin piridoksal, piridoksin ve piridoksamin formlarının biyolojik olarak erişilebilirliklerini in vitro koşullarda değerlendirmişlerdir. Bu çalışmada $\mathrm{B}_{6}$ vitamininin $\mathrm{PL}$, PN ve PM formları HPLC metodu kullanılarak ayrılmıştır. Ayrıca, in vitro insan sindirim (ağız, mide ve ince bağırsak) ortamı oluşturularak biyolojik olarak erişilebilirliği de incelenmiştir. Çalışma sonucunda $\mathrm{B}_{6}$ vitamini miktarı numunelerde 265 ile $1163 \mu \mathrm{g}$ $(100 \mathrm{~g})$ arasında olduğu gözlenmiştir. İ vitro sindirim sistemi aracılı̆̆ıla, ürünlerin ambalaj etiketlerindeki bilgilerin analiz sonucu elde edilen değerlerle karşılaştırılması sağlanmıştır. Etiket üzerindeki beyanlarla karşılaştırıldığında, 13 tahıl bazlı bebek mamasından 12 'sinin toplam $\mathrm{B}_{6}$ vitamini seviyelerini içerdiği tespit edilmiştir. Türk Gıda Kodeksi' ne göre, bebek gıdalarında izin verilen maksimum $\mathrm{B}_{6}$ vitamini sınırı, $0.35 \mathrm{mg} / 100 \mathrm{kcal}$ şeklindedir. Bu çalışmadaki ürünlerin üzerindeki kalori değerleri ise 384 ile 432 $\mathrm{kcal} / 100 \mathrm{~g}$ arasında değişmiştir. Bu bilgilere göre, toplam $\mathrm{B}_{6}$ vitamini değeri tüm ürünlerde maksimum limitin altında olduğu ve Türk Gıda Kodeksi' ne uygun olduğu gösterilmiştir. Ayrıca, ölçülen $\mathrm{B}_{6}$ vitamin sonuçları Amerikan Gıda Bileşimi Veritabanı (USDA) tarafindan bulunan sonuçlarla uyumlu olduğu da gösterilmiştir (Yaman ve Mızrak, 2019).

Yaman (2019)'da yaptığı çalışmada farklı ekmek çeşitlerinde doğal olarak bulunan $\mathrm{B}_{1}, \mathrm{~B}_{2}$ ve $\mathrm{B}_{6}$ vitaminlerinin in vitro biyoerişebilirliğini incelemiştir. Çalışmada vitamin içerikleri Yüksek Performanlı Sıvı Kromatografisi (HPLC) ile belirlenmiştir ve analiz sonuçlarında $\mathrm{B}_{6}$ vitamerlerinden olan $\mathrm{PN}$ formunun en yüksek olduğu ve yulaf içeren ekmeğin vitamin $\mathrm{B} 1, \mathrm{~B} 2$ ve B6 biyoerişilebilirliği karş̧laştırılan diğer ekmek türlerinden daha düşük olduğu bulunmuştur. Sonuçlar değerlendirildiğinde, günlük beslenmemizde ekmeğin yanında B grup vitamin açısından zengin besinler tüketilmesi gerektiği beyan edilmiş̧tir (Yaman, 2019).

\section{Sonuç}

$\mathrm{Bu}$ çalışmada, ilk aşamada Türk mutfağındaki geleneksel olan bazı besinlerin günlük alınması gereken B vitamini miktarının belirlenmesi, ikinci aşamada B vitaminin biyoyararlılı̆̆ hakkında bilgi edinilmesi ve son olarak da bu besinlerin günlük gereksinimleri karşılayıp karşılamadığının belirlenmesi amaçlanmıştır. Bu çalışma da sunulan veriler gıda bileşimi veritabanları, araştırma çalışmaları ve hasta danı̧̧manlığı için potansiyel kullanım alanları bulacaktır. Laboratuvar çalışma sonuçları değerlendirildiğinde, Türk mutfağındaki yemeklerin, B grubu vitamin değerleri bakımından oldukça zengin olduğu görülmektedir. B grubu açısından zengin olmasının sebebi ise içerisinde tam tahıl grubu, et, yumurta, baklagil ve yeşil yapraklı sebzeler bulunmasıdır. Ayrıca çalışma sonucunda, günlük gereksinimizi karşılayan B grubu vitamin sonuçları besinler arasında farklılık göstermiştir, bu durum ise B vitaminlerinin kimyasal olarak farklı formlarda ve miktarlarda olup farklı özellikler göstermesinden kaynaklanmaktadır. B grubu vitaminler suda eriyen vitaminler sınıflandırılmasında yer aldığı için pişirme sırasında kayıplar görülmektedir. Bu kayıpların yaşanmaması için yemeklerin pişirme sularının dökülmemesi gerekir çünkü haşlama sularını dökülmesi B grubu vitamin içeriklerini kaydadeğer düzeyde azaltmaktadır. Az suda haşlama veya suyun çektirilmesiyle yapılan pişirme yöntemi, vitamin kayıplarını minimum seviyeye ulaştırır. Yüksek derece ve ateşe yakın pişirilen etlerde pişirme sularının kaybolmasına bağlı olarak $\mathrm{B}_{2}, \mathrm{~B}_{12}$ ve folik asit gibi B grubu vitamin kayıpları meydana gelmektedir. Orta veya düşük sıcaklıkta kendi nemi ile pişirilmesi vitamin kayıplarını azaltabilir. Ayrıca, hazırlama ve saklama süreçlerinde veya sebzeleri yıkama aşamasında suda bekletmek bazı vitaminlerin suda çözünerek kaybolmasına sebep olabilmektedir. Türk mutfağının sahip olduğu geniş yemek kültüründeki besinler, temel pişirme ilkelerine göre hazırlanırsa daha sağlıklı olacaktır. Bu çalışmanın verileri, bireylerin ihtiyacına uygun şekillerde hazırlanan menülerin planlaması yapılırken vitamin kombinasyonunu sağlamak amacıyla göz önünde bulundurulabilir.

\section{Kaynakça}

Barut, İ. 2016. Niasin (B3) Vitamininin Yağ Grefti Sağ Kalımı Üzerine Etkisi. Gazi Üniversitesi, Tıp Fakültesi, Uzmanlık Tezi, 110s, Ankara.

Bingöl, G. 1977. Vitaminler ve Enzimler. Ankara Üniversitesi, Eczacılık Fakültesi Yayınları, Ders Kitabı Serisi, 90s, Ankara.

Boyacı, B.B. 2008. Zenginleştirilmiş Unlardan Farklı Koşullarda Üretilen Ekmeklerin Bazı B Vitamini İçeriklerinin İncelenmesi. Hacettepe Üniversitesi, Fen Bilimleri Enstitüsü, Doktora Tezi, 148s, Ankara.

Ciulu, M., Solinas, S., Floris, I., Panzanelli, A., Pilo, M. I., Piu, P. C., Sanna, G. 2011. RP-HPLC determination of water-soluble vitamins in honey. Talanta, 83(3), 924-929. 
Demirci, M. 2014. Beslenme, Gıda Teknoloji Derneği Yayınları, (5. Baskı) 370s, Tekirdağ

El-Arab, A. E., Ali, M., Hussein, L. 2004. Vitamin B1 profile of the Egyptian core foods and adequacy of intake. Journal of Food Composition and Analysis, 17(1), 81-97.

Ertaş, Y., Gezmen, M. 2013. Sağlıklı beslenmede Türk mutfak kültürünün yeri. Gümüşhane Üniversitesi Sağlık Bilimleri Dergisi 2(1), $117-136$.

Esteve, M. J., Farré, R., Frígola, A., García-Cantabella, J. M. 2001. Simultaneous determination of thiamin and riboflavin in mushrooms by liquid chromatography. Journal of Agricultural and Food Chemistry, 49(3), 1450-1454.

Güngör, K. 2003. Vitamin ve minerallerin dişhekimliğindeki önemi. Gazi Üniversitesi Diş Hekimliği Fakültesi Dergisi, 20(3), 51-56.

Kızıldemir, Ö. Öztürk, E., Sarışık, M. 2014. Türk mutfak kültürünün tarihsel gelişiminde yaşanan değişimler. Abant İzzet Baysal Üniversitesi Sosyal Bilimler Enstitüsü Dergisi, 14(3), 191-210.

Ndaw, S., Bergaentzle, M., Aoudé-Werner, D., Hasselmann, C. 2002. Enzymatic extraction procedure for the liquid chromatographic determination of niacin in foodstuffs. Food Chemistry, 78(1), 129-134.

Rose-Sallin, C., Blake, C. J., Genoud, D., Tagliaferri, E. G. 2001. Comparison of microbiological and HPLC-Fluorescence detection methods for determination of niacin in fortified food products. Food Chemistry, 73(4), 473-480.

Sampson, D. A., Eoff, L. A., Yan, X. L., Lorenz, K. 1995. Analysis of free and glycosylated vitamin B6 in wheat by high-performance liquid chromatography. Cereal Chemistry, 72(2), 217-220.

Samur, G. 2008. Vitaminler Mineraller ve Sağlığımız. Klasmat Matbaacılık, 32s, Ankara.

Tayar, M. Korkmaz, H.N., Özkeleş, E. 2013. Beslenme İlkeleri. Dora Yayınları, (2.Baskı) 368s, Bursa.

Yaman, M. 2019. Farklı ekmek çeşitlerinde doğal olarak bulunan vitamin $B_{1}, B_{2}$ ve $B_{6}$ 'nın in vitro biyoerişebilirliğinin incelenmesi. Avrupa Bilim ve Teknoloji Dergisi, (16), 758-764.

Yaman, M., Mizrak, Ö. F. (2019). Determination and evaluation of in vitro bioaccessibility of the pyridoxal, pyridoxine, and pyridoxamine forms of vitamin $\mathrm{B}_{6}$ in cereal-based baby foods. Food Chemistry, 125042. 